\title{
Protecting Economic Interests or the Right to Life? Perception of the European Court of Justice on Emergency Medical Services ${ }^{1}$
}

\author{
Jenna Uusitalo \\ Faculty of Law, \\ University of Helsinki \\ P.O. box 4, \\ Yliopistonkatu 3, \\ Helsinki FI-00014, Finland \\ E-mail: jenna.uusitalo@helsinki.fi
}

\begin{abstract}
European Union (EU) was founded to strengthen European integration through purely economic cooperation while disregarding human rights. However, throughout its existence the EU has been challenged to take a stand on human rights. In fact, the application and promotion of human rights has increased significantly in recent years, especially during the last 15 years, mainly thanks to the establishment of the Charter of Fundamental Rights in 2000. Through the selected cases concerning emergency medical services, this paper examines how the arguments of the European Court of Justice have eventually been shifting from purely economic ideology towards more human rights based approach. However, the article essentially argues that the full potential of human rights to support the claims that are inherently economic in their nature has not yet been utilized and therefore the essential aim of the Charter to strengthen human rights protection in the EU remains unachieved.
\end{abstract}

Keywords: Charter of the Fundamental Rights of the European Union, Court of Justice of the European Union, economic interests, emergency medical service, European Union, human rights

$\overline{1}$ The author would like to thank FinnHEMS Oy for financial support. 


\section{Introduction}

The European Coal and Steel Community (ECSC), as a predecessor to the presentday European Union (the EU), was founded after World War II to strengthen European integration through economic cooperation and interdependence (Karns \& Mingst, 2009, p. 160; Storney \& Turner, 2008). However, economic interests have never completely excluded the application of human rights, or fundamental rights as commonly referred in the EU context, from the scope of the EU law- even though their protection may not have been that visible. While the original protection of human rights started to evolve primarily from the case law of the Court of Justice of the European Union (CJEU), ${ }^{2}$ the highest point of the Union's contribution towards the recognition of human rights in their widest scope was reached in 2000 with the establishment of the Charter of the Fundamental Rights of the European Union (hereafter, the Charter). In fact, since the Charter obtained its legally binding force in 2009, human rights are nowadays required to be taken into account in every decision making process. (Reding, 2012; EC, 2011)

Human rights reflect the core values of mankind (Nowak, 2003, p. 1; Kerikmäe, Hamulàk \& Chochia, 2016, p. 99). Such an ideology is reaffirmed in the preamble of the Charter, which calls for need for human rights to be respected and protected in order to ensure a peaceful future of the EU. However, despite the increased recognition of human rights within the EU law especially during the past 15 years, human rights based arguments before the CJEU and in the Court's judgments still seem relatively constrained. Because the Charter aims to strengthen human rights by making them more visible, through the selected cases the present article examines how the arguments of the CJEU have eventually been shifting from purely economic ideology towards a more human rights oriented approach. Nevertheless, the article argues that the full potential of human rights to support the claims that are economic in their nature has not yet been utilized and the essential aim of the Charter has not yet been achieved. The research analysis in the present article is primarily conducted from the

2 In fact, the perception of the Court on human rights protection has developed from rather reluctant attitude to the superior recognition of human rights; In early human rights cases such as Stauder and Nold, the CJEU simply acknowledged that the fundamental rights belong in the integral part of the community law. The ground-breaking judgment was provided in Schmidberger in which the Court recognized that the fundamental human rights prevail over the EU law. However, various EU legislation that was primarily enacted to promote economic interests carry also the aspects of human rights protection; see, for example, Council Directive 2004/38/EC and Council Directive 2006/54/EC. 
perspective of the emergency medical service (EMS) because, in addition to the fundamental contribution to provide urgent treatment to patient who suffered an injury or a sudden onset of illness (Terveydenhuoltolaki, 2010, Art. 40(1)), EMS deals with the economic activities, such as employment costs and maintenance of the equipment, as well.

The article is structured in the way that after the introduction, Section Two provides a short factual background of the selected cases. Section Three engages in detailed analysis of the arguments. Finally, Section Four summarizes and concludes the findings.

\section{Brief overview of the cases}

The CJEU has issued a limited number of EMS related judgments which are essentially argued more or less from the economic viewpoints. Thus, EMS decisions are evaluated in conjunction with the cases concerning the pharmaceutical to see how far human rights based arguments could be expanded. Such a comparison is supported by the fact that, by looking beyond the generally invoked notion of public health protection, EMS and medicines have essentially been designed to safeguard the right to life and to limit unnecessary pain and suffering.

Practically all EMS cases were invoked to challenge the application of the competition rules, especially Article 106(2) of the Treaty on the Functioning of the European Union (TFEU) concerning services of general economic interest (SGEI), or Directive 2004/18/EC on public service contracts. ${ }^{3}$ In Ambulanz Glöckner, the private EMS operators sued an administrative district for nonrenewal of their authorization for EMS. According to the plaintiffs, refusal to grant the authorization granted medical aid operators a de facto monopoly on the market for emergency and patient transport services contrary to competition law articles. In Commission v. Germany [2010] the claim was filed to accuse Germany of failure to make public call on tenders to award contracts to public ambulance services thereby violating Article 106(2) of the TFEU and Directives

Article 106(2) states: "Undertakings entrusted with the operation of services of general economic interest or having the character of a revenue-producing monopoly shall be subject to the rules contained in the Treaties, in particular to the rules on competition, in so far as the application of such rules does not obstruct the performance, in law or in fact, of the particular tasks assigned to them. The development of trade must not be affected to such an extent as would be contrary to the interests of the Union." 
92/50/EEC and 2004/18/EC. The question of whether public procurement and competition rules prevent the authority responsible for maintaining health care to make an EMS contract with non-profit EMS providers was asked in Spezzino [2014]. The interpretation of Article 106 of the TFEU was also submitted to the preliminary reference in Spezzino. However, unlike in Ambulanz Glöckner and Commission v. Germany, in Spezzino the judgment was mainly reached by relying on the freedom of establishments and services under Articles 49 and 56 of the TFEU, and by referencing to Directive 2004/18/EC.

Notably, while the references in Spezzino were made to the Commission v. Germany as well, the Court widely applied the judgment of Blanco Pérez and Chao Gómez concerning the pharmaceuticals simultaneously-yet implicitlyemphasizing human rights related connections between medicines and economic interests. While EMS cases revolved mainly around the competition rules, pharmaceuticals sought to challenge the incompatibilities of the domestic laws in relations to Articles 49 and 56 of the TFEU. Blanco Pérez and Chao Gómez claimed that Spanish law had established excessively detailed rules on pharmacies and their proximity to create an obstacle to the free movement rules. In addition to Articles 49 and 56 of the TFEU, Apothekerkammar des Saarlandes [2009] also invoked Directive 2005/36/EC on professional qualifications to challenge the German law preventing the non-pharmacist from owning and operating pharmacies. In Venturini [2013] the plaintiffs argued that Italian law violated Article 49 of the TFEU by preventing qualified and registered pharmacists from selling certain pharmaceuticals outside the National Health Service. Interestingly, in all pharmaceutical cases the Court accepted the protection of public health as a justification to limit the freedoms of establishment and services. In EMS cases the public health claim relying specifically on the EU law was not invoked despite its being equivalently available. ${ }^{4}$

4 Article 168 of the TFEU contributing to protection of human health originally appeared in the Treaty of Maastricht (Art. 129) and was re-codified into the Treaty of Amsterdam (Art. 152) 


\section{Evaluating the arguments from the perspective of human rights}

\subsection{EMS cases usually lack expressed protection of human rights}

Judgments on EMS cases reflect the changed attitude of the CJEU towards human rights protection quite well. Whereas in Ambulanz Glöckner human rights seemed to be conspicuously absent, in Commission v. Germany they were partially recognized and in Spezzino the Court expressly acknowledged that the health and life of humans were among the interests protected by the EU and that EMS contribute to the protection of public health (Spezzino [2014], paras 56 and 59). Notwithstanding, the CJEU mentioned this connection very briefly, making no direct reference to any specific treaty article or elaborating this notion further. Such an omission does, in fact, support the perception according to which the court does not yet fully understand the connection between the EU law and human rights.

However, while the public health claim has conventionally not been invoked in relation to the competition rules, human rights arguments could have been applied in Ambulanz Glöckner and Commission v. Germany to strengthen the argument in relation to claims of EMS constituting SGEI. In fact, Germany did justify its actions in both cases relying on Article 106(2) of the TFEUbut mainly on an economic basis. In Ambulanz Glöckner Germany argued that only public operators were able to maintain the costs of EMS but failed to demonstrate why EMS could not have been guaranteed by the private operators. ${ }^{5}$ In the proceedings initiated by the Commission, Germany saw EMS as an exercise of public authority as it belonged to the emergency chain (Commission v. Germany [2010], paras 67-69). Needless to say, in both cases the arguments were unsuccessful. In the latter proceedings, however, Germany also argued that EMS forms an essential part of risk prevention and health protection, which the Court in fact accepted (Commission v. Germany [2010], para 65). However, both CJEU and Advocate General (AG) Trstenjak concluded that protection of public health and assistance for a person whose life is in danger are not limited to the tasks of the public authorities (Commission v. Germany [2010], para 80; Trstenjak [2010], para 79). Nevertheless, the remarkable aspect of the case is that it did engage in some discussion - although limited and slightly ambiguous - of EMS contributing to safeguard the lives of the people.

5 Germany claimed inter alia that EMS required investments in equipment and personnel, and that public operators were able to provide permanent standby service and similar quality as well as cover the costs of emergency transportation from the revenues received from the patient transportation (Ambulanz Glöckner [2010], paras $53-58)$ 
On the other hand, while especially the judgment of Ambulanz Glöckner reflects a rather traditional form of competition rulings emphasizing economic consideration and engaging in conventional competition law analysis, it did contain some implicit human rights protection aspects as well. In his opinion, AG Jacobs did acknowledge that rapid and high-quality ambulance service is a question of life and death and therefore of paramount importance to society as a whole (Jacobs [2001], para 150). Although the notion was pointed out and adopted by the CJEU in relation to the economic evaluation, it nevertheless reflects the implied recognition of EMS as essentially safeguarding the right to life. Furthermore, the fact that the Court excluded public EMS operators from the scope of Article 106(2) of the TFEU was essentially done to ensure that every citizen has access to EMS even in those situations in which public operators would be manifestly unable to satisfy its demands (Jacobs [2001], para 177; Ambulanz Glöckner [2001]). In fact, the reluctance of the CJEU to perceive public or non-profit-making EMS as SGEI was explained further by the notion that such a restriction of competition was not proportionate to the aim as there are other means, such as contracts, to ensure the availability of EMS across the whole territory of the Member State (Ambulanz Glöckner [2001], paras 55-57; Commission v. Germany [2010], paras 125-129; Trstenjak [2010], para 79). However, while the aim of the decision could be seen to safeguard human rights (i.e. to guarantee access to health care), the fact that the case lacked sufficiently recognizable human rights terminology illustrates the conventional economic approach by which the CJEU had been unable - or unwilling - to apply human rights. On the other hand, as demonstrated in Commission v. Germany, and especially in Spezzino, the attitude of the Court has started to change, most probably as a result of adoption of the Charter and increased emphasis on human rights within the EU in general.

In principle, all three rulings on EMS contained some elements of human rights protection. However, by reading the EMS cases one gets easily the impression that, even though the health protection aspects - and human rights - were briefly touched upon, in reality the parties lacked the adequate knowledge that EU law, in fact, contains provisions to support and strengthen such arguments. Therefore, while the increased recognition of EMS contributing to the protection of human rights is welcome, arguments could be enhanced further. Assistance can be sought, for instance, from the judgments concerning pharmaceuticals where the arguments are more tangible, although even in those cases they do not amount to full human rights protection. 


\subsection{Enhancing the arguments through pharmaceutical judgments}

Contrary to the judgments on EMS, the decisions on pharmaceuticals contain expressed preferences to the provisions of EU law protecting human health and life. In Venturini and Blanco Pérez, the CJEU recognized that reliable and good quality medicines do protect public health in accordance with Article 168(1) of the TFEU and Article 35 of the Charter (Venturini [2013], paras 40-41; Blanco Pérez and Chao Gómez [2010], paras 64-65; Wahl [2013], para 82; Poiares Maduro [2009], para 2). In Apothekerkammar des Saarlandes, on the other hand, the Court acknowledged the importance of taking health and life of people into account while considering the case (Apothekerkammar des Saarlandes [2009], para 19). ${ }^{6}$ The essential ideology in all cases was constructed upon the notion that unnecessary or incorrect consumption of medical products can cause serious harm to health even without the patient realizing it, so that Member States should be able to control such risks to human health despite uncertainty about the existence or extent of such risk (Apothekerkammar des Saarlandes [2009], para 30-32; Venturini [2013], para 60; Blanco Pérez and Chao Gómez [2010], para 74; Wahl [2013], para 104).

From the purely human rights perspective, the concession to the protection of fundamental rights is delightful but nevertheless somewhat constrained — or at least ambiguous. While the arguments on human rights terms are considerably more extensive in pharmaceutical cases than in EMS judgments, all cases were eventually litigated on an economic basis. Thus, the judgments did not, for example, include the explicit evaluation of how the justifiable restrictions of Articles 49 and 56 of the TFEU in relation to pharmacies de facto safeguard the prohibition of torture and inhumane or degrading treatment by ensuring the availability of reliable and good quality medicines for the patient who actually needs them. Simultaneously, the notion presented in Apothekerkammar des Saarlandes ([2009], paras 33-34) of the misuse of drugs leading to the waste of financial resources and exposing the public health and financial balance of the social security system to danger could have been elaborated further by analysing how abuse of drugs may lead to social exclusion. Such alienation not only subjects the drug addict to the inhumane treatment and violates his human dignity, but also increases the need for social services and reduces the available work force, thereby affecting national economy (Piris, 2009, p. 9). A similar

6 Advocate General Bot emphasized in his opinion also that qualified pharmacist ensures adequate guarantees of quality of the medicines as well as performs various tasks, including, e.g., the distribution of information on the proper use of the drugs to the patients that contributes to the protection of public health (Bot [2008], paras 48-51). 
public health claim could be made in relation to EMS to justify the need for the functioning EMS to avoid undesirable loss of life - whether the death of the patient or a stroke which essentially cuts an individual off the society. ${ }^{7}$

On the other hand, despite the still prevailing absence of substantive human rights arguments in the CJEU, the cases on pharmaceuticals do indicate that the Court is increasingly applying human rights in its proceedings. The pharmaceutical cases and the economic evaluations in them therefore do actually provide valuable grounds to relate even more substantial human rights arguments to the claims. The expressed legal grounds for such arguments is, in fact, already found in the EU law.

\subsection{Various legal grounds on which to protect the right to EMS}

As the pharmaceutical cases demonstrated, when the case before the CJEU concerns health care, the application of Articles 35 of the Charter and 168 of the TFEU should nowadays seem pretty much self-evident. ${ }^{8}$ However, whereas those provisions were expressly mentioned in Venturini and Blanco Pérez, none of the EMS cases invoked such a connection - even though the CJEU did argue in terms of health and human lives especially in Spezzino. ${ }^{9}$ In fact, the protection of health within the EU has generally been perceived to relate to preventative measures such as actions against tobacco and alcohol products or obesity (Council Directive 2014/40/EU; EC, 2006; Fae, 2012). As all of these

7 Of course, medical evaluations are, and should always be, based on case-by-case evaluation. Therefore, under some circumstances such as in a case of an old, unconscious person without good medical prognosis, loss of life can, in fact, be regarded as protecting and promoting human dignity rather than being perceived as an economic loss.

8 Article 35 of the Charter states: "Everyone has the right of access to preventative health care and the right to benefit from medical treatment under the conditions established by national laws and practices. A high level of human health protection shall be ensured in the definition and implementation of all the Union's policies and activities." Article 168 of the TFEU states inter alia: "A high level of human health protection shall be ensured in the definition and implementation of all Union policies and activities. Union action, which shall complement national policies, shall be directed towards improving public health, preventing physical and mental illness and diseases, and obviating sources of danger to physical and mental health."

9 Ambulanz Glöckner was litigated prior to the drafting process of Charter of Fundamental Rights. However, the CJEU dealing with Commission v. Germany the Charter had already obtained a certain status of guiding the EU law in human rights matters, and in time of Spezzino it had obtained its legally binding force. Article 168 of the TFEU, on the other hand, was introduced to the EU legislation already by the Treaty of Maastricht, thus being available to all of EMS proceedings. 
measures contribute to the preventative protection of public health in the purest sense, it appears quite understandable that EMS providing an urgent treatment to an already sick or injured person is not easily perceived as within the concept of 'preventative' care. However, Articles 35 of the Charter and 168 of the TFEU are mutually applicable to EMS as well.

In fact, Article 35 of the Charter not only establishes the right of access to preventative health care but also confers the right to benefit from medical treatment. Therefore, although EMS is invoked after an incident has occurred, by intervening in the situation the paramedics have a significant role in preventing the injury or illness relapsing. Simultaneously, the paramedics are required to refer patients, their relatives and other individuals to psychosocial support services where necessary, which in itself constitutes as a form of preventative health care providing help prior to trauma escalating into a more severe mental health issue (Terveydenhuoltolaki, 2010, Art. 40(1)(3)). The right to benefit from the medical treatment, on the other hand, links EMS to other human rights as the medical treatment generally aims inter alia to prevent diseases, ease pain and heal illnesses, all contributing to enhance the quality of life and preventing the undesirable loss of life - all these being the rights nowadays codified in the Charter. Thus, Article 35 of the Charter is also indisputably applicable to EMS.

However, according to Article 51(1) of the Charter, the provisions of it are addressed primarily to the EU institutions and to the Member States only when they are implementing Union law. Such a limited field of application imposes some challenges because individuals themselves cannot directly enforce the rights enshrining from the Charter. On the other hand, fairly equivalent protection is provided by Article 168 of the TFEU establishing a high level of human health protection. In relation to EMS, this provision can refer inter alia to the sufficient number of ambulances or the appropriate paramedical training schemes both of which contribute to protecting human health. Furthermore, being a part of the TFEU, this provision can be relied upon in practically every health-related case, even when the Charter is not invoked. On the other hand, even though the Charter might lack the grounds for its substantive application, ${ }^{10}$ it can be referred to as a supplementary document which emphasizes the codified values of the Union.

However, while some CJEU cases, such as Spezzino and Blanco Pérez and Chao Cómez, have acknowledged the importance of health and health care, they have nevertheless failed to understand the fundamental interconnection

10 For example, the case does not concern the implementation of the EU law but rather the interpretation of certain legal provisions. 
between health care and other human rights. In order to enhance the arguments for the importance of EMS, Articles 35 of the Charter and 168 of the TFEU can be supplemented with other human rights codified in the Charter. Depending on the issue in question, the application of the Charter can flow from human dignity and the right to life to working conditions and freedom to conduct a business. Similarly, the protection of human rights guaranteed in Article 6 of the Treaty of the European Union (TEU) offers extensively grounds for the arguments as the provision requires that the EU respects the rights deriving from European Convention of Human Rights, the Charter and the constitutional traditions. Therefore, even though the case substantially claims the distortion of the market, for example by creating obstacles to market access for the private EMS operators contrary to the EU law, it is advisable to the parties of the proceeding strengthen their arguments by also emphasizing the rights of the patient to obtain the required medical treatment within the sufficient time limit in order to sustain the right to life. The arguments could be enhanced even further if combined with the medical research evidence. For example, in a case of cardiac arrest, medical research shows the defibrillation started within three to five minutes after the collapse can produce survival rates up to $70 \%$ whereas each minute of delay to resuscitate reduces the probability of survival (Perkins et al., 2015, p. 83). Open market access increases the number of ambulances, and competition actually enhances quality of the service as the service providers are required to maintain sufficient - or even better-standards in comparison to the competing undertakings to be able to win the competitive tendering. Increased number of the ambulances reduces long time intervals from dispatch to scene because more ambulances are capable of responding to the emergency call despite simultaneous on-going missions. Therefore, the free market economy improves also the timely access to emergency care and ultimately safeguards the patients' right to life. Considering the continuously increased recognition and application of human rights, such arguments before the Court seem relatively difficult to refute by an opponent or to be ignored by the CJEU. Therefore, the human rights based arguments do significantly strengthen the position of the party relying on such rhetoric - even in the proceedings that are basically economic in their nature. However, human rights cannot be protected and promoted solely by the human rights oriented lawyers, but the judges of the CJEU need to be educated to understand and accept the importance and potential of human rights as well.

In sum, the lack of human rights based arguments before the CJEU has resulted rather from insufficient understanding of human rights and their potential to support economic claims than the absence of the sufficient grounds provided by the EU law. It is thus sufficient to conclude that while the arguments before and 
of the CJEU has been shifting from purely economic ideology towards a more human rights based approach, the full potential of human rights to support the claims that are inherently economic in their nature has not yet been utilized.

\section{Conclusion}

Human rights, or fundamental rights, as generally referred in the context of the EU law, reflect common values which need to be respected and protected in order to ensure a peaceful future of the EU. As has been illustrated above, human rights oriented arguments have been evolving gradually in the CJEU case law over the decades and especially since the introduction of the Charter in 2000. However, while the Charter is currently the most tangible human rights instrument within the EU, human rights rhetoric may be derived from other sources as well. Over the years not only the case law but the Treaties as well have been enhanced to the point in which the Treaties de facto provide significant opportunities to enforce human rights in the EU. Therefore, while the CJEU does occasionally seem to lack a comprehensive or even coherent perception of human rights, it does not exclude or hinder the potential to pursue even more aggressive and extensive human rights based arguments in the Court - rather vice versa. The more human rights related cases are referred to the Court; the more consistently the case law can develop-without compromising the economic interests.

Jenna Uusitalo is a PhD candidate at the University of Helsinki. She holds a master's degree in law from Tallinn Law School, Tallinn University of Technology, where she is currently giving visiting lectures. Her research interests concentrate on various human rights questions relating to health care. 


\section{References}

Advocate General Bot [2008], Opinion of the joined cases C-171/07 to C-172/07.

Advocate General Jacobs [2001], Opinion of the case C-475/99.

Advocate General Poiares Maduro [2009], Opinion of the joined cases C-570/07 to C-571/07.

Advocate General Trstenjak [2010], Opinion of the case C-160/08.

Advocate General Wahl [2013], Opinion of the joined cases C-159/12 to 161/12.

Ambulanz Glöckner v. Landkreis Sudwestpfalz [2001] ECR I-8089, C-475/99.

Apothekerkammer des Saarlandes and Others and Helga Neumann-Seiwert v Saarland and Ministerium für Justiz, Gesundheit und Soziales ('Apothekerkammer des Saarlandes') [2009] ECR I-04171, Joined cases C-171/07 and C-172/07.

Blanco Pérez and Chao Gómez [2010] = José Manuel Blanco Pérez and María del Pilar Chao Gómez v Consejería de Salud y Servicios Sanitariosand Principado de Asturias [2010] ECR I-04629, Joined cases C-570/07 and C-571/07.

Commission v. Germany [2010] ECR I-03713, C-160/08.

Council Directive 92/50/EC relating to the coordination of procedures for the award of public service contracts, The Official Journal of the European Union, L 209, 24.07.1992.

Council Directive 2004/18/EC on the coordination of procedures for the award of public works contracts, public supply contracts and public service contracts, The Official Journal of the European Union, L 134, 31.03.2004.

Council Directive 2004/38/EC on the right of citizens of the Union and their family members to ove and reside freely within the territory of the Member State, The Official Journal of the European Union, L 158/, 30.04.2004.

Council Directive 2006/54/EC on the implementation of the principle of equal opportunities and equal treatment of men and women in matters of employment and occupation, The Official Journal of the European Union, L 204, 26.6.2006.

Council Directive 2014/40/EU on the approximation of the laws, regulations and administrative provisions of the Member States concerning the manufacture, presentation and sale of tobacco and related products, The Official Journal of the European Union, L 127, 2.04.2014.

EC (2006), The EU Strategy to Support Member States in Reducing Alcohol Related Harm, Commission of the European Communities, Brussels, COM625.

EC (2011), European Commission Operational Guidance on Taking Account Fundamental Rights in Commission Impact Assessments, Commission Staff Working Paper, SEC 567, 6.05.2011, pp. 3-4. 
Faeh, A. (2012), 'Obesity in Europe: the Strategy of the European Union from a Public Health Law Perspective,' European Journal of Health Law, vol. 19, no. 1, pp. 69-86. https://doi.org/10.1163/157180912X615149

Karns, M. \& Mingst, K. (2009), International Organizations: The Politics and Processes of Global Governance, Boulder CO; Lynne Rienne Publisher.

Kerikmäe, T.; Hamulák, O. \& Chochia, A. (2016), 'A historical study of contemporary human rights: deviation or extinction?' Acta Baltica Historiae et Philosophiae Scientiarum, vol. 4, no. 2, pp. 98-115. https://doi.org/10.11590/abhps.2016.2.06

Nold v. Commission [1974] ECR 491, C-4/73.

Nowak, M. (2003), Introduction to International Human Rights Regime, Leiden: Brill Academic Publishers.

Perkins, G. D. et al. (2015), 'European Resuscitation Council Guidelines for Resuscitation 2015: Adult Basic Life Support and Automated External Defibrillation,' Resucitation, vol. 95, no. 81, pp. 81-99. https://doi.org/10.1016/j. resuscitation.2015.07.015

Piris, J.-C. (2009), The Future of Europe: Towards a Two-Speed EU? Cambridge: Cambridge University Press.

Reding, V. (2012), The Binding EU Charter of Fundamental Rights: Key Trends Two Years Later, Brussels: The Centre of European Studies, 16.4.2012, pp. 1-7.

Schmidberger, Internationale Transport und Planzuge v. Austria [2003] ECR I-5659, C-112/00.

Spezzino [2014] = Azienda sanitaria locale n. 5 and Others v San Lorenzo Soc. coop. sociale and Croce Verde Cogema cooperativa sociale Onlus [2014] EJC 11 December 2014, C-113/13.

Stauder v. City of Ulm [1969] ECR 419, C-29/69.

Storey, T. \& Turner, C. (2008), Unlocking EU Law, London: Hodder Education, pp. 4-5.

Terveydenhuoltolaki 1326/2010, Finnish Health Care Act, Government of Finland.

Venturini $[2013]=$ Alessandra Venturini v ASL Varese and Others Maria Rosa Gramegna v ASL Lodi and Others and Anna Muzzio v ASL Pavia and Others [2010] ECJ 5 December 2013, Joined cases C-159/12 to C-161/12. 